AGRO EKONOMI, Vol 29, Issue 2, December 2018, Page.310-322

DOI : http://doi.org/10.22146/ae.37011

ISSN 0215-8787 (print), ISSN 2541-1616 (online)

Available at https://jurnal.ugm.ac.id/jae/

\title{
THE INFLUENCE OF INDIVIDUAL AND ENVIRONMENTAL FACTORS ON SMALL BUSINESS PERFORMANCE OF BRIQUETTES IN BANGUNHARJO VILLAGE, BANTUL REGENCY
}

\section{Pengaruh Faktor-Faktor Individu dan Lingkungan terhadap Kinerja Usaha Kecil Briket di Desa Bangunharjo Kabupaten Bantul}

\author{
Syikhristani ${ }^{1}$, Jamhari ${ }^{2}$, Dwidjono Hadi Darwanto ${ }^{3}$ \\ ${ }^{1}$ Master Students of Agribusiness Management, Faculty of Agriculture, \\ Universitas Gadjah Mada \\ ${ }^{2,3}$ Faculty of Agriculture, Universitas Gadjah Mada \\ Jl. Flora No. 1 Bulaksumur, 55281 Yogyakarta, Telp. (0274) 555675 \\ syikhristani@gmail.com
}

Submitted: 16 July 2018; Revised: 10 October 2018; Accepted: 7 December 2018

\begin{abstract}
This study aims to understand: (1) the application level of the individual factor and work environment to the employee of the coconut shell briquette small business in Bangunharjo Village, Bantul Regency, (2) the performance level of the employee of the coconut shell briquette small business in Bangunharjo Village, Bantul Regency, (3) the effectiveness of the individual factor and work environment toward the employee's performance of the coconut shell briquette small business in Bangunharjo Village, Bantul Regency. The location and the sample of the research were determined in purpose based on the certain consideration and criteria through a case study. The method used in this study comprises of two independent variables and one dependent variable. The number of respondent taken was 31 people consisting of business owner and employee. The questionnaire technique being used was questionnaire with likert scale measurement $1-5$ from attitude strongly disagree to strongly agree and analyzed by utilizing Statistical Product and Service Solutions (SPSS) program version 24 in order to obtain the descriptive data analysis, the correlation of person product moment and double linear regression with 5\% significancy range. The result of the analysis reveals: (1) the level of application of individual factors and the work environment for employees are in a good category; (2) the measurement through the employee's performance is good; (3) both individual factor and work environment have a significant positive effect on employee's performance, proven by the discovery of adjusted $\mathrm{R}$ squared value that is 0.727 on the determination coefficient.
\end{abstract}

Keywords: Briquettes, Environment, Individual, Performance

Syikhristiani, Jamhari, \& Darwanto, D.H. (2018) The Influence of Individual and Environmental Factors on Small Business Performance of Briquettes in Bangunharjo Village, Bantul Regency. Agro Ekonomi, 29(2) : 310-322 


\section{INTISARI}

Penelitian ini bertujuan untuk: (1) mengetahui tingkat penerapan faktor individu dan lingkungan manajemen pada karyawan usaha kecil briket tempurung kelapa di Desa Bangunharjo Kabupaten Bantul; (2) mengetahui tingkat kinerja karyawan usaha kecil briket tempurung kelapa di Desa Bangunharjo Kabupaten Bantul; (3) mengetahui pengaruh faktor individu dan lingkungan manajemen terhadap kinerja karyawan usaha kecil briket tempurung kelapa di Desa Bangunharjo Kabupaten Bantul. Penentuan lokasi dan respoden ditentukan secara purposive atas dasar pertimbangan dan kriteria tertentu, melalui satu studi kasus di Desa Bangunharjo, Kabupaten Bantul, Daerah Istimewa Yogyakarta. Metode penelitian melibatkan dua variabel independen dan satu variabel dependen. Jumlah responden yang diambil sebanyak 31 orang terdiri dari pemilik usaha dan karyawan. Teknik angket menggunakan kuesioner dengan pengukuran skala likert 1-5 dari sikap sangat tidak setuju sampai sangat setuju, dibantu program SPSS versi 24 untuk menghitung analisis data deskriptif, korelasi person product moment, dan regresi linier berganda dengan tingkat signifikansi 5\%. Hasil analisis menunjukkan: (1) tingkat penerapan faktor individu dan lingkungan manajemen bagi karyawan berada pada kategori baik; (2) pengukuran melalui kinerja karyawan tergolong baik; (3) faktor individu dan lingkungan manajemen keduanya berpengaruh signifikan positif terhadap kinerja karyawan, ini dibuktikan dengan ditemukannya nilai adjusted $R$ squared sebesar 0,727 pada koefisien determinasi.

Kata kunci: Briket, Individu, Kinerja, Lingkungan

\section{INTRODUCTION}

From the commodity of coconut, only the primary products are utilized so far. Whereas, its derivative products have not been widely used, especially by-products and waste. If developed, it can increase the value-added of products (Directorate General of Plantation of the Ministry of Agriculture, 2013; Saepulah et al., 2017).

One of the prospects to increase the income value is by utilizing and managing coconut tree derivatives into downstream coconut industry such as a small business that has been run in Bangunharjo Village, Bantul Regency, Yogyakarta. The small business here deploys coconut shell as the raw material, then it is converted into a briquette product. In fact, the process of production surely cannot be separated from the employees.

The important consideration for the author in this study is to help business owners' efforts empower local community of Bangunharjo Village so that they can take part and be involved in improving and promoting village economy as well as expanding science study on business employee performance. Previously, a study has been conducted on Small and Medium Enterprises (UKM) business strategies of coconut shell charcoal briquettes as a comparison in Bangunharjo Village, Bantul Regency.

Regarding the performance of the employee, of course it cannot be separated 
from many factors that can affect employee's performance. The result of the research (Sudibyo et al., 2014) stated that the factors having real effect on the employee's performance are the understanding of Standard Operating Procedure (SOP) and employee's employment relationship. Environmental and individual factors have a significant positive impact on employee's performance based on the hypothesis testing (Natassia and Indria, 2016).

Performance achievement is influenced by two factors : (1) individual factors including: the concentration of a person in work that is influenced by the cognitive and emotional intelligence; and (2) environmental factors, for instance: clear job description, adequate authority, target, effective communication pattern, harmonious working relationship, dynamic work climate, career opportunities and adequate working facilities, while the dimension of employee performance measurement uses Human Resource Scorecard (HRS) which identifies human resources competence and emphasizes more on performance orientation in every activity (Mangkunegara, 2017).

In order to find out how the level of relationship between individual factor and the work environment, and the effectiveness of the two factors above with the performance of small size business for briquettes (made from coconut shell) in Bangunharjo Village,
Bantul Regency, it is necessary to conduct research aiming to understand: (1) the level of application of individual factors and management environment of the coconut shell briquettes small business in Bangunharjo Village, Bantul Regency; (2) the level of employee's performance of coconut shell briquette small business in Bangunharjo Village, Bantul Regency; (3) the effectiveness of individual factor and work environment on the employee's performance of coconut shell briquette small business in Bangunharjo Village, Bantul Regency.

\section{METHODS}

The location of this research was determined in purpose for one case study at a small business of coconut shell briquettes in Bangunharjo Village, Bantul Regency under the consideration: (i) the quality in producing coconut shell briquette has an excellent heat that is equal to 7,424 Kal g1 based on Laboratory test result Integrated Research and Testing (LPPT) of Gadjah Mada University (UGM) with number 00390/01/LPPT/III/2015 and has exceeded the quality of briquette quality, that is $\geq 5,000 \mathrm{Kal}$ g- 1 according to Indonesian National Standard (SNI) with number.I/6235/2000; (ii) the briquette produced is not only for the local scale, but also more than that. It has penetrated the world market specifically to the middle east region, American continent and even to 
Europe; (iii) the willingness of the business owner to provide the necessary data for the purpose of the research and to grant the permit as the research location; and (iv) the number of small enterprise employees of coconut shell briquettes is qualified as the sample material of the study. It is in accordance with some suggestions from four suggestions on the size of the study sample suggested (Sugiyono, 2007; Nurizzati, 2012).

About 30 respondents were chosen based on the two independent variables and one dependent variable under criteria: (i) permanent employees who acted as active workers and had work experience with owner more than two years; (ii) employees whose main products and daily routine work as business actors of coconut shell briquettes in Bangunharjo Village, Bantul Regency; and (iii) employees who are willing to fill out the questionnaire objectively, honestly and correctly in accordance with their respective opinions by using conscience as well as the real circumstances that occur in the field. In order to strengthen the results of the study, the researcher one respondent (business owner) was added under the consideration that he or she is a person who has more than 10 years experience as the business man with direct interviews related to the formulation of research data.

Census was used as the research method, by treating all population members (the employees of coconut shell charcoal briquette enterprise) as a respondent. Primary and secondary data were elicited for analysis. The variables in this study were presented using ordinal scale, measured by identifying the average number of scores. The measurement was done in the form of statements referring to likert scale with five alternative responses were given, strongly agree: 5; agree: 4; neutral: 3 ; disagree: 2 ; and strongly disagree: 1. Questionnaire assessment results were then transformed into an interval scale using sequential interval method. Descriptive statistics was used to analyze data from each of the variables described by using table and describing the collected data objectively or according to the context (Mulyana et al., 2015)

Table 1. The likert scale and the interpretation range scale for the used category

\begin{tabular}{lr}
\hline Answer's range category & Scale's range \\
\hline Very bad & $1.00-1.79$ \\
Bad & $1.80-2.59$ \\
Neutral (Good enough) & $2.60-3.39$ \\
Good & $3.40-4.19$ \\
Very good & $4.20-5.00$ \\
\hline Source: Primary data analysis $(2018)$
\end{tabular}

According to (Riduwan, 2010; Mulyana et al., 2015), likert scale is used to measure opinions and perceptions of respondents toward an event. The level of assessment used in this study ranged from one to five, from the lowest scoring score 
(negative) to the highest score (positive). The scale formula of the research scale can be calculated $(((5-1) / 5)-0.01)=0.79$. The descriptive analysis was carried out using the average value for the purpose of analysis. It was really insightful to know the answer's weight of respondents toward each statement item, in which it is divided into five categories as seen in Table 1.

Answering research objectives (number one and two) was done by looking at the range of the average value scale that had been interpreted for each position of the Likert scale category. Decision making was based on: first, if descriptive analysis of the average value obtained from all items of independent variable statements $\mathrm{X}<4.20$ then $\mathrm{H}_{1}$ is accepted and vice versa, if the average value obtained from all items of independent variable statements $X \geq 4.20$ then $\mathrm{H}_{1}$ is rejected; second, if descriptive analysis of the average value obtained from all dependent variable statements $Y \geq 3.40$ then $H_{1}$ is accepted and vice versa, if the average value obtained from all dependent variable statement items $\mathrm{Y}<3.40$ then $\mathrm{H}_{1}$ is rejected.

On the other hand, to investigate research objective number three for simultaneous tests is based on: first, significance value of $5 \%(\alpha=0.05)$; second, $\mathrm{t}$ distribution with degrees of freedom (n$\mathrm{k}$ ); third, if F-count $>$ F-table or sig $t$ value $<0.05$, then the hypothesis that there is a significant positive influence between individual factors $\left(\mathrm{X}_{1}\right)$ and management environment $\left(\mathrm{X}_{2}\right)$ on employee performance (Y) is accepted, however, if the value of F-count $<$ F-table or sig $t$ value $>0.05$, then the hypothesis that there is a significant positive influence between individual factors $\left(\mathrm{X}_{1}\right)$ and management environment $\left(\mathrm{X}_{2}\right)$ on employee performance $(\mathrm{Y})$ is rejected. The formula used was as follows.

$$
\mathrm{Kk}=\mathrm{a}+\mathrm{b}_{1} \mathrm{i}+\mathrm{b}_{2} \mathrm{~L}+\mathrm{e}_{\mathrm{t}}
$$

Information :

$\mathrm{Kk}=$ Employee performance is the dependent variable $(\mathrm{Y})$

$\mathrm{a} \quad=$ Constant (intercept value)

$b_{1} b_{2}=$ The regression direction coefficient of the independent variable is the individual factors $\left(\mathrm{X}_{1}\right)$ and work environment $\left(\mathrm{X}_{2}\right)$ $\mathrm{e}_{\mathrm{t}} \quad=$ Prediction error (erorr term)

$\mathrm{i} \quad=$ Individual $\left(\mathrm{X}_{1}\right)$

$\mathrm{L}=$ Environment $\left(\mathrm{X}_{2}\right)$

Multiple linear regression analysis was done through classical assumption test, whether the data are normally distributed, free of multicollinearity, and do not have heteroscedasticity. It was then followed by coefficient of determination, simultaneous test.

\section{RESULTS AND DISCUSSION}

The characteristic of the respondents were grouped by gender, age, education level, marital status and employment's duration with a statement that the number of female employees were more than male 
and the difference in comparison was $22.6 \%$ or around seven people. The majority age of the employees was between 26-50 years with percentage of $61.29 \%$. The age of employees that were $(<26)$ and $(>50)$ was $19.35 \%$. Around $71 \%$ of employees have completed school. Besides, related to the martal status, $74.19 \%$ of employees working in this business were mostly married. This indicates that employees have generally had a family dependent that they have to support. The last, the working hours of the employees stated that $87.1 \%$ of employees worked for two to four years, while the remaining $12.9 \%$ work more than four years.

Validity test was conducted on 30 respondents using pearson product moment correlation coefficient. The questionnaire items of each statement are valid if the value is positive and ( $>0.3)$. If the value is $(<0.3)$ then the statement item is declared invalid and removed from the questionnaire or removed (Nurizzati, 2012). The result of validity test of individual factor questionnaire $\left(\mathrm{X}_{1}\right)$, work environment $\left(\mathrm{X}_{2}\right)$ and employee's performance $(Y)$ showed that as many as 48 items statement in the research questionnaire after tested, there were five items of statement of variable declared invalid and removed since the value of $\mathrm{t}$-count which obtained from the value of r-table $(0.361)$ at $(\alpha=0.05)$ with there are two items at $\left(\mathrm{X}_{2}\right)$ Variable, $\left(\mathrm{X}_{2}\right)$ two items and $(Y)$ one item. Then the remaining 43 item statements after validity test is valid and feasible for forwarded. The result of r-count individual factor is 0.796 and work environment is $0.802>0.361$ ) showed strong and significant correlation between variable $\mathrm{X}$ and variable $\mathrm{Y}$.

A construct or variable is said to be reliable if it gives a value $(\alpha)>0.70$ (Nunually, 1978; Muda et al., 2014). The results of the calculation of the reliability test of this study after previously tested, the validity with the valid statement and feasible to continue, then it obtained value of cronbach alpha individual factor of 0.887 ; environmental factor 0.895 and the performance of 0.740 shows that the overall value of the variables in the study is reliable, because the value found is greater than 0.70 .

Respondents' answers to individual factors includes in the good category level. Table 2 showed the description of the highest respondent's rating based on the true intention of employees in carrying out their duties, maintaining honesty, always paying attention to the needs of the number of employees for these three have a large influence on business performance and what needs to be considered is the level of education that supports low-rated work. The important points to take into consideration is about the employees who have a high attitude and enthusiasm in advancing the business in accordance with the business mission. It has to be encouraged by efforts to explore their 
potential continuously. Hence in the future, they can work more competitively and competently as a guarantee of customer satisfaction while continuing to create and produce qualified products. Always maintaining the best quality of goods is a major factor in the realization of the vision of the coconut shell briquettes in Banguhjaro Village, Bantul Regency. This performance is related to the company or individual level by looking at Human Resources (HR) becomes an important factor in determining the achievement of organizational goals (Muda et al., 2014).

According to (Shaffril and Uli, 2010), with a good work environment, it can bring benefits to the organization and prevent disloyalty and dissatisfaction, and it also can encourage positive behavior and atmosphere to the employees.
Respondents' answers on work environment factors categorized as good. From Table 3, it can be seen that the statement of the existing employees that they have fulfilled the needs in managing business is still considered low by the respondents. It has a close relationship with individual factors related to the statement of the number of employees affecting the performance that is considered high. Thus it can be ascertained that the respondents need more qualified members in their field. The reflection of the business attitude that must be maintained by all employees based on the highest rating is about the statement that employees never abuse the authority entrusted by the company. It means that they maintain mutual trust between business owners and employees and vice versa. The attitude of leaders towards subordinates

Table 2. The descriptive of the individual factor's statement average score $\left(\mathrm{X}_{1}\right)$

\begin{tabular}{llllllr}
\hline \multirow{2}{*}{ The statement item of the individual factor's $\left(\mathrm{X}_{1}\right)$} & \multicolumn{9}{l}{ The } & \multicolumn{7}{l}{ answer's score (percentage) } & \multirow{2}{*}{ Mean } \\
\hline Able to control emotion (i1) & 0.0 & 6.7 & 23.3 & 43.3 & 26.7 & 3.90 \\
Cognitive competence (i2) & 0.0 & 3.3 & 26.7 & 43.3 & 26.7 & 3.93 \\
Expertise in work (i3) & 3.3 & 3.3 & 13.3 & 46.7 & 33.3 & 4.03 \\
Education background to support job description (i4) & 0.0 & 20.0 & 46.7 & 20.0 & 13.3 & 3.27 \\
Family supports carrier (i5) & 0.0 & 6.7 & 20.0 & 40.0 & 33.3 & 4.00 \\
Number of employee influences & 3.3 & 10.0 & 0.0 & 33.3 & 53.3 & 4.23 \\
performance (i6) & 3.3 & 0.0 & 23.3 & 43.3 & 30.0 & 3.97 \\
Response toward job's responsibility (i7) & 3.3 & 0.0 & 20.0 & 46.7 & 30.0 & 4.00 \\
Response toward reward (i8) & 3.3 & 13.3 & 16.7 & 33.3 & 33.3 & 3.80 \\
Response toward the level of satisfaction (i9) & 0.0 & 0.0 & 23.3 & 46.7 & 30.0 & 4.07 \\
The confidence level (i10) & 3.3 & 3.3 & 3.3 & 36.7 & 53.3 & 4.33 \\
The work motive level (i11) & 0.0 & 0.0 & 23.3 & 53.3 & 23.3 & 4.00 \\
The perseverance level (i12) & 0.0 & 0.0 & 13.3 & 50.0 & 36.7 & 4.23 \\
Honesty (i13) & 0.0 & 10.0 & 10.0 & 50.0 & 30.0 & 4.00 \\
The interest level (i14) & & & & & & 3.98 \\
\hline The average score of the individual factor $\left(\mathrm{X}_{1}\right)$ & & & & &
\end{tabular}

Source: Primary data analysis (2018) 
Table 3. The descriptive of the work environment statement average score $\left(\mathrm{X}_{2}\right)$

\begin{tabular}{lllllll}
\hline \multirow{2}{*}{ The statement item of the work environment $\left(\mathrm{X}_{2}\right)$} & \multicolumn{9}{l}{ Answer's score (percentage) } & \multirow{2}{*}{ Mean } \\
\hline Upholding trust from the company (L1) & 1 & 2 & 3 & 4 & 5 & \\
Giving challenge toward the work target (L2) & 0.0 & 0.0 & 3.3 & 43.3 & 53.3 & 4.50 \\
Able to communicate well (L3) & 3.3 & 0.0 & 40.0 & 36.7 & 20.0 & 3.70 \\
Harmony increases performance (L4) & 3.3 & 10.0 & 26.7 & 40.0 & 20.0 & 3.63 \\
The cooperative relationship (L5) & 0.0 & 0.0 & 10.0 & 56.7 & 33.3 & 4.23 \\
Convenient office (L6) & 3.3 & 0.0 & 13.3 & 46.7 & 36.7 & 4.13 \\
Adaptavility toward the work environment (L7) & 0.0 & 3.3 & 16.7 & 43.3 & 36.7 & 4.13 \\
The equipment matches the need (L8) & 0.0 & 0.0 & 23.3 & 50.0 & 26.7 & 4.03 \\
The sufficient facilities (L9) & 0.0 & 3.3 & 20.0 & 56.7 & 20.0 & 3.93 \\
The availability of facility and infrastructure (L10) & 0.0 & 10.0 & 36.7 & 43.3 & 10.0 & 3.53 \\
Sufficient work tool (L11) & 3.3 & 3.3 & 23.3 & 46.7 & 23.3 & 3.83 \\
The sufficient number of employee (L12) & 0.0 & 3.3 & 26.7 & 36.7 & 33.3 & 4.00 \\
Leading by example (L13) & 0.0 & 16.7 & 30.0 & 43.3 & 10.0 & 3.47 \\
Leader's attitude influences performance (L14) & 3.3 & 0.0 & 6.7 & 36.7 & 53.3 & 4.37 \\
Subsidy fits the need (L15) & 0.0 & 3.3 & 6.7 & 36.7 & 53.3 & 4.40 \\
Giving reward (L16) & 0.0 & 0.0 & 16.7 & 53.3 & 30.0 & 4.13 \\
Structure is in accordance with work distribution (L17) & 3.3 & 3.3 & 23.3 & 30.0 & 40.0 & 4.00 \\
The report system runs well (L18) & 3.3 & 3.3 & 16.7 & 53.3 & 26.7 & 4.03 \\
Obey toward the established rule (L19) & 6.7 & 0.0 & 13.3 & 50.0 & 30.0 & 4.00 \\
Understanding the main task (L20) & 0.0 & 0.0 & 10.0 & 63.3 & 30.0 & 3.97 \\
The work form matches situation (L21) & 0.0 & 0.0 & 23.3 & 53.3 & 23.3 & 4.17 \\
The average score of the work environment (X) & & & & & & 4.00 \\
\hline
\end{tabular}

Source: Primary data analysis (2018)

Table 4. The average score of performance achievement factor influence(X)

\begin{tabular}{lcr}
\hline The performance achievement factor influence & Mean & Information \\
\hline Individual factor $\left(\mathrm{X}_{1}\right)$ & 3.98 & Good \\
Work environment $\left(\mathrm{X}_{2}\right)$ & 4.01 & Good \\
\hline The average score of independent variable $(\mathrm{X})$ & 3.99 & Good \\
\hline
\end{tabular}

Source: Primary data analysis (2018)

must be built harmoniously. It is important

to be maintained so that the performance provided by employees and business owners is not disrupted yet improves the continuity of the business. With unpredictable business environment and intense business competition, companies are required to achieve certain standards by improving their performance to align with such large demands, otherwise, many problems will arise, including risks to close the business that has been run (Muda et al., 2014)

Table 4 shows that the influence of work performance factors categorized as good. Individual factors and work environment. It is necessary to be considered and improved as it has an important role in developing the business in order to continue being advanced. The 
important role of individuals lies on how to foster mutual care and be able to manage business performance by doing their best to contribute at work and to create the management environment that could satisfy all parties involved in the business, either the business owner, the employees, or customers.

Table 5 illustrates attitude assessment of the respondents' responses to the measurement of the employee's performance through the statements about competence and work orientation. All of them are categorized as good. The statement considered as low existing on the point of "providing training for employees". The highest score is on the point of "the level of difference in providing remuneration by the business owners as well as its relation to work and the effort should be comparable to what the employees do according to the standard and workload". Meanwhile, the statements of work efficiency, process of managing products, knowledge of the business, and anticipation of the business will increase if the basic statements can be fulfilled properly. Performance measures are suggested to be a reference for business owners in adjusting the situations and conditions of employees at this time in order to optimize and utilize existing resources so that businesses gain better performance. This condition will be better if the efforts implemented are on the attitude upholding justice to all so as to have a positive impact on improving the

Table 5. The descriptive of the respondent answer related to the performance (Y)

\begin{tabular}{|c|c|c|c|c|c|c|}
\hline \multirow{2}{*}{ The statement item of the employee's performance } & \multicolumn{5}{|c|}{ Answer score (percentage) } & \multirow{2}{*}{ Mean } \\
\hline & 1 & 2 & 3 & 4 & 5 & \\
\hline Improving the HR perform & 3.3 & 3.3 & 6.7 & 66.7 & 20.0 & 3.97 \\
\hline processing $\mathrm{b}$ & 3.3 & 0.0 & 33.3 & 46.7 & 16.7 & 3.73 \\
\hline Acknov & 6.7 & 3.3 & 33.3 & 43.3 & 13.3 & 3.53 \\
\hline Anticipatio & 3.3 & 0.0 & 36.7 & 50.0 & 10.0 & 3.63 \\
\hline A good quality HR hired (K5) & 0.0 & 0.0 & 30.0 & 43.3 & 26.7 & 3.97 \\
\hline Providing t & 3.3 & 6.7 & 40.0 & 43.3 & 6.7 & 3.43 \\
\hline Workload a & 0.0 & 6.7 & 20.0 & 33.3 & 40.0 & 4.07 \\
\hline The difference in giving remuneration (K8) & 0.0 & 6.7 & 13.3 & 40.0 & 40.0 & 4.13 \\
\hline & & & & & & 3.81 \\
\hline
\end{tabular}

Source: Primary data analysis (2018)

Table 6. The skewness and kurtosis ratios' score to the normality testing

\begin{tabular}{llllrrr}
\hline \multicolumn{1}{c}{ Variabel } & \multicolumn{3}{c}{ Skewness } & \multicolumn{3}{c}{ Kurtosis } \\
& Statistic & Std. error & Rasio & Statistic & Std. error & \multicolumn{1}{c}{ Rasio } \\
\hline Individual factor $\left(\mathrm{X}_{1}\right)$ & -0.157 & 0.427 & -0.367 & -0.504 & 0.833 & -0.605 \\
Work environment $\left(\mathrm{X}_{2}\right)$ & -0.544 & 0.427 & -1.274 & 1.054 & 0.833 & 1.265 \\
Performance $(\mathrm{Y})$ & -0.244 & 0.427 & -0.571 & -0.184 & 0.833 & -0.221 \\
\hline
\end{tabular}

Source: Primary data analysis (2018) 
quality of all HR as a measure of business success. The performance of employees in carrying out each business process has an important role as the pivotal role determining the business success

Commission employees consider that their performance is influenced by awards, job design and training and development opportunities, while for the management style of the research findings have impeded employee's performance (Nzuve and Njambi, 2015).

For ensuring whether the data had been in normal distribution or not, the detection toward the normality of residuals by looking at the value of skewness ratio and kurtosis ratio could be done. If it is on minus two up to positive two, it means that the data have been in normally distributed. The data are shown Table 6.

The data of multiple linear regression calculation results through univariate analysis in Table 7 provide a description of the business that someone wants life in fulfilling adequate economic needs by getting a better income so that the main factor in determining work choices is an attraction. If not, it is similar to the reality occurred in briquette business, namely, a decrease in the number of employees and this attitude needs to be maintained so that the business can develop well. It means that every employee who works has a different attitude of satisfaction and efficiency so that it has a variety of positive and negative impacts and depends on how someone rates according to his/her feeling. The results of this study prove that, first, the research data have a positive impact on employee performance. This result is in line with the direction of the study (Satiyono and Bodroastuti, 2012) stating that individual factor has a positive and significant influence on performance satisfaction. In other words, the better individual factors, the higher the employee

Table 7. The result of the double linear regression analysis coefficients ${ }^{\mathrm{a}}$

\begin{tabular}{lllrrr}
\hline Variable & \multicolumn{2}{l}{ Unstandardized coefficients } & $\begin{array}{r}\text { Standardized } \\
\text { coefficients } \\
\text { beta }\end{array}$ & t count & Sig \\
& $\mathrm{B}$ & Standard error & & 0.994 & 0.329 \\
Constanta & $2.441^{\text {ns }}$ & 2.455 & 0.361 & 2.687 & 0.012 \\
Individual factor $\left(\mathrm{X}_{1}\right)$ & $0.191^{*}$ & 0.071 & 0.574 & 4.280 & 0.000 \\
Work environment $\left(\mathrm{X}_{2}\right)$ & $0.219^{* *}$ & 0.51 & & & 0.746 \\
\hline$R$ Squared & & & & & 0.727 \\
Adjusted $R$ Squared & & & & $39.600^{* *}$ \\
\hline F count
\end{tabular}

Source: Primary data analysis (2018)

Information:

** Significant effect on the level of 1\% (0.01); (F table 5.45); ( $\mathrm{t}$ table 2.77)

* Significant effect on the level of 5\% (0.05); ( $\mathrm{t}$ table 2.05)

ns (not significant) 
job satisfaction. Second, the influence of management environment related to the individual factor that was affected by the needs towards the number of employees. The results show that the management environment is the most influential factor on the performance of employees of small briquette businesses in Bangunharjo Village. It is in line with the research by (Ibrahim and Primiana, 2015) about the business environment stating that it has a significant influence on organizational performance. It means that organizational performance could be improved through improving the business environment. Third is about the influence towards the fair amount of the employee's wage for each employee given by the company. The employees expect that it could be relevant to know what respondents' opinions are. According to the respondents' opinions, the reward given to the employee should be various based on the skill and performance of the employee.

\section{CONCLUSION AND SUGGESTION}

There are some conclusions that could be drawn from this research instance: first, level of application individual factors and work environment very good is on seriousness, honesty, upholding the trust of the authority given by the company, through example and discipline from a leader, maintain the harmony atmosphere of working relationship, it becomes the main capital as a source of business strength to always be well guarded; second, the level in measuring performance attitudes through the identification of HR good competencies, especially the provision of remuneration and work through the wages given in proportion; third, the influence of performance achievement factor both have a significant positive effect on the performance.

Based on the study that the researcher has done, the researcher offer some suggestions for instance related to the education background of the employee to support his or her job should need more attention by the business owner since the average value obtained compared with other statement item is still considered low by the respondents. It could be enhanced by improving the effectiveness and efficiency of the business through training skills, both in individual and group or team, Adjusted to the level of work requirements; second, the company in providing remuneration is expected to be in accordance with the level of burden of work difficulties and the wages provided should be proportional to the return of services performed and the provision of benefits or rewards gives more value of benefits that is in accordance with the needs of employees; third, the government or related institution with the management of Micro Small Medium business (UMKM) is expected to be more serious in supporting the particular small-scale business that 
prioritize empowerment to the society, has a contribution in improving the economy and employment opportunities so that business sustainability at the village level can be guaranteed its existence and legality; fourth, the next researcher is expected to add the variables apart from the effect of performance achievement factor such as comparing employee performance with productivity variable from the individual side and the work environment as well as factor from the need of raw materials production business.

\section{REFERENCES}

Ibrahim, R., \& Primiana, I. (2015). Influence Business Environment On The Organization Performance. International Journal of Scientific \& Technology Research, 4(04), 283-293.

Mangkunegara, A. A. A. P. (2017). Evaluasi Kinerja SDM. Edisi Kedelapan. Bandung: Refika Aditama.156 p.

Muda, I., Rafiki, A., \& Harahap, M. R. (2014). Factors Influencing Employees' Performance : A Study on the Islamic Banks in Indonesia. International Journal of Business and Social Science, 5(2), 73-80.

Mulyana, V. C., Sulistyowati, L., \& Karyani, T. (2015). Persepsi Petani Cabai Merah terhadap Faktor-Faktor yang
Mempengaruhi Pemilihan Koperasi sebagai Sumber Pembiayaan. Jurnal Ilmu Pertanian dan Peternakan, $3(1), 1-8$.

Natassia, R., \& Indria, V. (2016). Pengaruh Faktor Lingkungan Kerja dan Faktor Individu terhadap Prestasi Kerja Karyawan pada PT.Pos Indonesia (Persero) Kantor Area II Padang. Journal of Economic and Economic Education, 4(2), 233-239.

Nurizzati, Y. (2012). Peranan Statistika dalam Penelitian Sosial Ekonomi. Edueksos: Jurnal Pendidikan Sosial \& Ekonomi, 1(1), 91-105.

Nzuve, S. N. M., \& Njambi, M. P. (2015). Factors Perceived to Influence Employees' Performance : A Case of The Independent Electoral and Boundaries Commission. Scienta Socialis Journals, 10(2), 88-99.

Saepulah, A., Julita, U., Yusuf, T., \& Cahyanto, T. (2017). Inovasi Produk Olahan Pangan melalui Pemanfaatan Limbah Organik Ampas Kelapa untuk Meningkatkan Ekonomi Masyarakat Kabupaten Bandung Jawa Barat. Istek: Jurnal Kajian Islam, Sains dan Teknologi, X(1), $1-15$.

Satiyono, D., \& Bodroastuti, T. (2012). Pengaruh Faktor Individual, Faktor 
Agro Ekonomi Vol. 29/Issue. 2, December 2018

Sosial, dan Faktor Utama dalam

Pekerjaan terhadap Kepuasan Kerja (Studi pada Staf Kantor PT . Sinar Pantja Djaja Semarang). Jurnal Kajian Akuntansi dan Bisnis, 1(1), $1-23$.

Shaffril, H. A. M., \& Uli, J. (2010). The Influence of Socio-Demographic Factors on Work Performance Among Employees of Government
Agriculture Agencies in Malaysia. The Journal of International Social Research, 3(10), 459-469.

Sudibyo, Hartono, S., \& Maas, A. (2014). Analisis Kinerja Karyawan Divisi Mill dan Boiler PT Gula Putih Mataram. Jurnal Agro Ekonomi, 25(2), 205-215. Retrieved from https://jurnal.ugm.ac.id/jae 